Koloskova Olena, Khilchevska Victoria, Bilyk Galyna. Self-assessment of inters on the efficiency of online preparation for the licensed integrated exam "Krok 3. General medical training" in a pandemic COVID-19 (analysis results of anonymous survey). Journal of Education, Health and Sport. 2021;11(2):101-106. eISSN 2391-8306. DOI http://dx.doi.org/10.12775/JEHS.2021.11.2.011 https://apcz.umk.pl/czasopisma/index.php/JEHS/article/view/JEHS.2021.11.2.011

https://zenodo.org/record/4568925

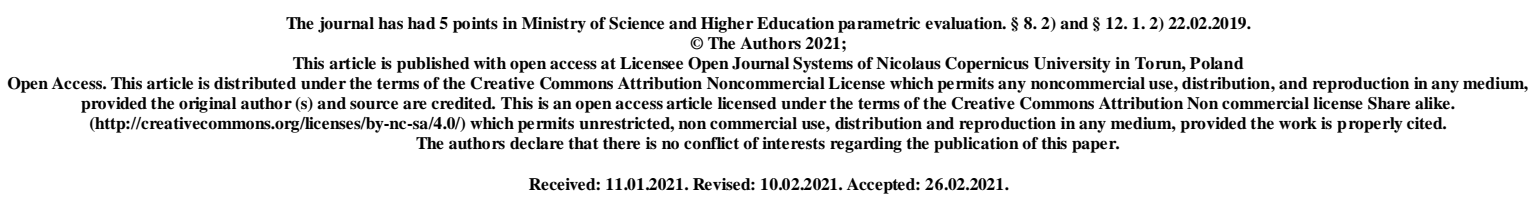

UDC: $378.147 .22 .018 .43: 004$

\title{
SELF-ASSESSMENT OF INTERS ON THE EFFICIENCY OF ONLINE PREPARATION FOR THE LICENSED INTEGRATED EXAM "KROK 3. GENERAL MEDICAL TRAINING" IN A PANDEMIC COVID-19 (ANALYSIS RESULTS OF ANONYMOUS SURVEY)
}

\section{Olena Koloskova, Victoria Khilchevska, Galyna Bilyk}

\section{Bukovinian State Medical University}

Department of Pediatrics and Children's Infectious Diseases

Olena Koloskova - Professor, Head of Department of Pediatrics and Children's Infectious Diseases Victoria Khilchevska - PhD, Associate Professor

Galyna Bilyk - PhD, Associate Professor

\section{Abstract}

An anonymous survey of interns of the specialty "Pediatrics" on the quality of training interns for the licensed integrated exam "KROK 3. General medical training" at the Department of Pediatrics and Children's Infectious Diseases of Bukovinian State Medical University was conducted using the google form.

The main purpose of the survey was to assess the effectiveness of training interns for the licensed test exam "KROK 3. General medical training" in the context of distance learning. It is shown that interns positively assess the quality of training in a distance form for passing this exam. Most interns point to the effectiveness of consultations of teachers and experts of creating tests in preparation for the exam. According to $60.0 \%$ of interns, the most 
effective component of preparation for the LIE "KROK 3. General medical training" was training on the program of the module "Emergencies", $25.0 \%$ noted thematic consultations conducted by teachers of the department immediately before the exam, and according to $15.0 \%$ of respondents, the best component was preparation for rector's tests. The most useful and informative for interns were consultations on emergencies in pediatrics $50.0 \%$ of responses), neurology and psychiatry (20.0\%), cardiology (15.0\%) and radiation medicine $(15.0 \%)$.

Keywords: postgraduate education; interns; pediatrics; distance learning.

Introduction. The pandemic caused by COVID-19 and the introduction of strict quarantine measures has affected all sectors of human life. The educational process in higher medical educational institutions under quarantine conditions is carried out online using various communication platforms. The need for social distancing has led to a significant restriction of real communication between participants in the educational process of higher medical education including interns and patients of clinics, teachers and doctors. On the one hand this situation affected the quality of training, and on the other hand, the self-assessment of their knowledge and skills.

Recent research in Great Britain have shown that sixth-year medical students note the predominant influence on their own readiness for independent medical activity in practical training rather than theoretical studies. The abolition or limitation of the practical part of the stuing during the pandemic significantly reduced self-esteem of students and their readiness for professional activity and confidence in their ability [1].

The standard for assessing the quality of postgraduate training of interns in Ukraine is the exam "KROK 3. General medical training " [2]. Preparation for this exam is mainly focused on strengthening and deepening the level of mastering professional knowledge and practical skills, as well as on the theoretical knowledge of interns [3].

The introduction of elements of distance learning has demonstrated its effectiveness as one of the components of diverse methods of training interns for passing the test licensed exam "KROK 3. General medical training" [4].

In particular, in the Bukovinian State Medical University (BSMU) of the Ministry of Health of Ukraine the systematic preparation of interns for passing this exam includes a set of educational and monitoring activities, namely, training at clinical departments under the program of the thematic module "Emergencies", carrying out complex tests in the format "KROK 3", thematic advice on exam profiles. At the same time, the adaptation of the proven 
system of preparation for teaching exclusively online is new for both teachers and applicants for education.

The opinion of interns regarding the value and effectiveness of online preparation for the integrated test exam should be decisive for the future changes in the forms of the educational process in the internship.

Goal of research. To evaluate the effectiveness of preparation for the licensed test exam "KROK 3. General medical training" in the context of distance learning at the Department of Pediatrics and Children's Infectious Diseases of BSMU by analyzing the results of an anonymous survey of interns in the specialty "Pediatrics".

Material and methods. In the survey conducted after passing the exam "KROK 3. General medical training "in November 2020, 20 second-year interns in the specialty" Pediatrics" took part who successfully passed this exam. The female sex predominated among the respondents (95.0\%). 55.0\% of interns studied on contract basis, and $45.0 \%$ on a state order. It should be noted that the extramural cycle of studying took place at the clinical training bases for interns in the usual format, and the full-time cycle was conducted online. Preparation for the exam was carried out in the form of online distance learning. The individual elements of the studying the interns had to go full-time during the first year of study (module "Emergencies", written tests). During the quarantine period caused by the COVID-19 pandemic, testing of interns in educational and supervisory modes was organized using the online platform Moodle, and interns were consulted by teachers using Google Meet in the form of video conferencing.

At the Department of Pediatrics and Children's Infectious Diseases, additional consultations were held by a freelance expert of the Pediatric Testing Center on the algorithm for solving tests, their structure, format, writing techniques etc.

Upon completion of exam "KROK 3", interns were offered to evaluate the effectiveness of all components of the training system using a questionnaire developed at the department. In addition, interns expressed their attitude towards online learning in general. The anonymous survey was conducted using Google Forms, an online platform for conducting individual surveys that requires the participant to $\log$ in to their account to enter answers. In order to maintain anonymity, e-mail addresses of respondents were not collected. The questions of the survey related to the general assessment of distance learning technologies, the assessment of the effectiveness of individual elements of training, information support of the distance stage of preparation for the exam "KROK 3. General medical training", as well as self-assessment of the level of training and the level of 
knowledge in emergency conditions. The advantages and disadvantages of distance learning at the stage of preparing interns for the exam were analyzed in detail. The survey results were collected and analyzed graphically for each question in Google Form.

Results and discussion. In general, the interns were satisfied with the preparation for the Licensed Integrated Exam "KROK 3. General Medical Training" both during face-to-face training and remotely during the pandemic. According to $60.0 \%$ of interns, the most effective component of preparation for the LIE "KROK 3. General medical training" was training on the program of the module "Emergencies", $25.0 \%$ noted thematic consultations conducted by teachers of the department immediately before the exam, and according to $15.0 \%$ of respondents, the best component was preparation for rector's tests. The most useful and informative for interns were consultations on emergencies in pediatrics (50.0\% of responses), neurology and psychiatry $(20.0 \%)$, cardiology (15.0\%) and radiation medicine $(15.0 \%)$.

The most acceptable form of the educational process for interns in preparation for passing the exam "KROK 3" according to the survey is full-time (50.0\% of respondents) or intramural-distance $(45.0 \%)$ forms of education. Only one $(5.0 \%)$ future pediatrician appreciated and preferred distance learning. 55.0\% of interns were in favor of monitoring the level of knowledge on emergency conditions for the remote form.

It is interesting that despite the sufficient skills and abilities to work with gadgets, easy to use interactive and multimedia educational materials, the need for students to constantly improve information and communication technologies [5], medical applicants often do not support online learning, which actually demonstrated our survey. For example, at the Medical University of Vienna, the proportion of such first-year students reached only $12 \%$ [6].

Every fourth $(25.0 \%)$ intern had technical problems in the process of on-line education and preparation for the exam, respectively, $75.0 \%$ of interns worked confidently from a technical point of view. Most of the problems were related to the availability and quality of the Internet (connection problems, insufficient speed) and technical difficulties (sound, video etc.).

In general, the majority of interns $(60.0 \%)$ did not notice any problems during the distance preparation for the exam "KROK 3. General medical training", and $40.0 \%$ of respondents identified the need to combine it with practice in a hospital as the main obstacle in preparing for the exam. According to the analysis of the questionnaire, none of the pediatric interns considered the proposed volume of educational material to be excessive, did not note personal disorganization or insufficient knowledge of computer technologies. The 
vast majority of interns $(85.0 \%)$ noted the convenience and ease of use of the Google Meet video conferencing service.

Separate questions of the survey concerned the interns' self-assessment of their activity and the effectiveness of preparation for a fairly important exam. The analysis of the survey showed that $75.0 \%$ of interns consider the level of self-discipline and self-preparation for the licensed integrated exam "KROK 3 " to be sufficient. $15.0 \%$ of the respondents define it as high, two respondents $(10.0 \%)$ as low, which did not particularly affect on the effectiveness of passing the exam.

On the question of whether the training helps to pass the exam "KROK 3. General medical training" raises the level of knowledge of interns for the diagnosis and aid in emergencies $75.0 \%$ interns responded positively. As a result, $65.0 \%$ of pediatric interns defined their level of knowledge on emergency conditions as average, and 35.0\% as high.

The test expert of the Testing Center presented to the interns an algorithm for the sequence of solving tests in the "KROK 3" format. As a result, 95.0\% of the interns considered it useful to conduct this seminar, and 5.0\% were undecided about the answer. According to the respondents, the explanation of the algorithm and methodology for solving tests of the "KROK 3" format in 50.0\% of cases effectively helped in solving complex or "unknown" tests, a third (35.0\%) of respondents used this method when solving all tests of the 2020 booklet, and only $10.0 \%$ solved the tests without using this technique, and 1 intern was undecided in the answer $(5.0 \%)$.

Conclusions. Interns in the specialty "Pediatrics" generally positively assess the organization and quality of preparation for passing the licensed integrated exam "KROK 3. General medical training "at the Department of Pediatrics and Children's Infectious Diseases and in general at the Bukovinian State Medical University. Most often, interns when switching to a distance learning format had problems due to the need to combine preparation for the exam with work in a hospital in a correspondence course, less often they noted technical problems. The overwhelming majority of interns, when preparing for the exam when preparing for the exam, find it effective to consult teachers and experts of creating tests.

\section{References}

1. Byung Choi, Lavandan Jegatheeswaran, Amal Minocha, Michel Alhilani, Maria Nakhoul, Ernest Mutengesa The impact of the COVID-19 pandemic on final year medical students in the United Kingdom: a national survey// BMC Med Educ. 2020; 20: 206. doi: 10.1186/s12909-020-02117-1. 
2. Lisovyi V.M. V.A Kapustnyk., V.V Viun Pro stan ta perspektyvy pidhotovky likariv-interniv u Kharkivskomu natsionalnomu medychnomu universyteti [On the state and prospects of training interns at Kharkiv National Medical University]// Zbirnyk materialiv XII naukovo-metodychnoi konferentsii, prysviachenii 210-y richnytsi Kharkivskoho natsionalnoho medychnoho universytetu «Suchasnyi stan ta perspektyvy pidhotovky likarivinterniv u Kharkivskomu natsionalnomu medychnomu universyteti» [Collection of materials of the XII scientific-methodical conference dedicated to the 210th anniversary of Kharkiv National Medical University "Current state and prospects of training interns at Kharkiv National Medical University"]. Kharkiv, 2014; 3-8. (in Ukrainian)

3. Koloskova, O.K., L.A. Ivanova, S. I. Prunchak. Hotovnist likariv-interniv do napysannia testovoho ispytu "KROK 3" yak kryterii efektyvnosti vuzivskoi pidhotovky [Readiness of interns to write a test exam "KROK 3" as a criterion for the effectiveness of university training] / Materialy Vseukrainskoi navchalno-naukovoi konferentsii z mizhnarodnoiu uchastiu "Vprovadzhennia kredytno-modulnoi systemy orhanizatsii navchalnoho protsesu u VM(F)NZUkrainy: rezultaty, problemy ta perspektyvy" [Materials of the All-Ukrainian educational and scientific conference with international participation "The introduction of a credit-modular system for organizing the educational process in the VM (F) NZU Ukraine: results, problems and prospects"] // Medychna osvita, 2010;3:24-26. (in Ukrainian)

4. Koloskova O.K., Khilchevska, V. S., Bohutska, N. K. Systema dystantsiinoho navchannia yak efektyvna skladova pidhotovky likariv-interniv do litsenziinoho intehrovanoho ispytu «KROK 3. Zahalna likarska pidhotovka» [Distance learning system as an effective component of training interns for the licensed integrated exam "KROK 3. General medical training"] / Bukovynskyi medychnyi visnyk, 2011;5(59):141-142. (in Ukrainian)

5. Wilkinson A, While AE, Roberts J. Measurement of information and communication technology experience and attitudes to e-learning of students in the healthcare professions: integrative review. J Adv Nurs. 2009 Apr;65(4):755-72. doi: 10.1111/j.13652648.2008.04924.x. Epub 2009 Feb 9. PMID: 19228242.

6. Link T.M., Marz R. Computer literacy and attitudes towards e-learning among first year medical students. BMC Med Educ. 2006 Jun 19;6:34. doi: 10.1186/1472-6920-6-34. 